\title{
UJI EFEKTIVITAS MEDIA INTERAKTIF INTEGRASI NASIONAL UNTUK PERKULIAHAN PENDIDIKAN PANCASILA DAN KEWARGANEGARAAN
}

\author{
Mohammad Muhyidin Nurzaelani dan Rusdi Kasman \\ Fakultas Keguruan dan Ilmu Pendidikan \\ Universitas Ibn Khaldun Bogor \\ Jl. KH. Sholeh Iskandar KM. 2 Bogor \\ m.muhyidin@uika-bogor.ac.id
}

\begin{abstract}
Abstrak: Media interaktif merupakan salah satu perantara yang digunakan untuk menyampaikan pesan dalam pembelajaran agar mahasiswa dapat memahami materi yang disampaikan oleh dosen. Tujuan penelitian ini adalah untuk menguji efektivitas penggunaan media interaktif Integrasi Nasional untuk perkuliahan Pendidikan Pancasila dan Kewarganegaraan. Uji efektivitas media interaktif dilakukan untuk mengukur seberapa efektif media interaktif integrasi nasional dapat meningkatkan aktivitas belajar dan hasil belajar mahasiswa dalam perkuliahan Pendidikan Pancasila dan Kewarganegaraan. Data efektifitas media interaktif integrasi nasional terhadap hasil belajar dalam penelitian ini dilihat dari presentase mahasiswa yang memperoleh nilai kuis di atas nilai minimal kelulusan. Hasil penelitian menunjukkan bahwa media interaktif integrasi nasional berbasis mobile learning dinilai sangat efektif untuk digunakan berdasarkan penilaian hasil tes mahasiswa dimana $86 \%$ mahasiswa memperoleh nilai di atas nilai minimal, dan penilaian aktivitas mahasiswa oleh observer dengan presentase rata-rata kefektivan sebesar $82 \%$ dengan kategori sangat efektif.
\end{abstract}

Kata Kunci: Uji Efektifitas, Integrasi Nasional, Pendidikan Pancasila dan Kewarganegaraan.

\section{PENDAHULUAN}

Indonesia memiliki anugerah keanekaragaman suku bangsa, agama, ras, bahasa, budaya, adat istiadat, dan sebagainya yang menjadikan Indonesia adalah Bangsa yang besar. Para pendiri negara menyadari bahwa Bangsa Indonesia merupakan bangsa yang majemuk sehingga meninggikan semboyan "Bhineka Tunggal Ika" dan mengharuskan setiap langkah dan kebijakan negara dalam kehidupan berbangsa dan bernegara diarahkan untuk memperkuat persatuan dan kesatuan.

Integrasi Nasional dalam kondisi kekinian memiliki tantangan yang sangat beragam. Tantangan tersebut diidentifikasi sesuai dengan Ketetapan MPR Nomor V/MPR/2000 tentang Pemantapan Persatuan dan Kesatuan dan Kondisi Bangsa Indonesia saat ini 
meliputi (Pimpinan MPR dan Badan Sosialisasi MPR RI Periode 20142019): (1) Nilai-nilai agama dan nilainilai budaya bangsa tidak dijadikan etika; (2) Konflik sosial budaya; (3) Penegakan hukum tidak berjalan; (4) Perilaku ekonomi yang berlangsung dengan praktek korupsi, kolusi, dan nepotisme; (5) Sistem politik tidak berjalan dengan baik; (6) Peralihan kekuasaan yang sering menimbulkan konflik; (7) Masih berlangsungnya pelaksanaan kehidupan bermasyarakat yang mengabaikan proses demokrasi; Penyalahgunaan kekuasaan;

Globalisasi dalam kehidupan politik, ekonomi, sosial, dan budaya; dan (9) Kurangnya pemahaman, penghayatan, dan kepercayaan akan nilai-nilai Pancasila.

Kondisi tersebut di atas dapat menyebabkan disintegrasi bangsa. Pemuda sebagai penerus bangsa harus memiliki pemahaman akan pentingnya integrasi nasional. Mahasiswa sebagai bagian dari pemuda yang akan menjalankan roda pemerintahan di masa mendatang perlu memiliki rasa Bhineka Tunggal Ika yang tinggi. Oleh karena itu pembelajaran tentang integrasi nasional sangat diperlukan bagi mahasiswa. Pembelajaran integrasi nasional dalam perkuliahan di Universitas Ibn Khaldun Bogor terdapat pada mata kuliah Pendidikan Pancasila dan Kewarganegaraan.

Perkembangan teknologi dan informasi saat ini berdampak pula pada bidang pendidikan, yang menyebabkan terjadi perubahan kebutuhan belajar. Media sebagai salah satu perantara dalam pembelajaran yang digunakan untuk menyampaikan pesan memiliki fungsi yang penting dalam proses pembelajaran saat ini. Media interaktif merupakan salah satu media pembelajaran yang saat ini telah banyak digunakan dalam proses pembelajaran. Media interaktif (Nurzaelani dan Kasman 2018) adalah media yang membawa pesan-pesan atau informasi yang bertujuan untuk pendidikan dimana pengguna dan media dapat saling berinteraksi.

Media interaktif dapat membuat peserta didik dapat belajar lebih aktif dan dapat membuat pembelajaran menjadi lebih bermakna. Munir (2008) dalam Sari dan Susanti (2016) mengemukakan bahwa kelebihan dari media pembelajaran secara interaktif antara lain: (1) dapat memberikan pemahaman yang lebih dalam terhadap materi pembelajaran yang sedang 
dibahas, karena dapat menjelaskan konsep yang sulit menjadi mudah atau lebih sederhana, (2) dapat menjelaskan materi pembelajaran atau objek yang abstrak menjadi konkrit, (3) membantu mengajar menyajikan materi pembelajaran menjadi lebih mudah dan cepat, sehingga peserta didikpun mudah dipahami, lama diingat dan mudah diungkapkan kembali, (4) menarik dan membangkitkan minat, motivasi, aktivitas, dan kreatifitas belajar peserta didik, serta dapat menghibur peserta didik, (5) memancing partisipasi peserta didik dalam proses pembelajaran da memberikan kesan yang mendalam dalam pikiran peserta didik, (6) materi pelajaran yang sudah dipelajari dapat diulang kembali (playback), dan lain sebagainya.

Saat ini telah dikembangkan sebuah media interaktif pembelajaran integrasi nasional untuk perkuliahan Pendidikan Pancasila dan Kewarganegaraan. Berdasarkan hasil penelitian sebelumnya, media interaktif tergolong valid dan dapat digunakan untuk pembelajaran sesuai dengan hasil uji validitas ahli media, ahli konten, dan ahli desain pembelajaran. Hasil tersebut akan dilanjutkan untuk melihat tingkat efektivitas dari media pembelajaran interaktif integrasi nasional yang telah dikembangkan tersebut. Tingkat efektivitas media interaktif yang telah dikembangkan dinilai dari aktivitas dan hasil belajar mahasiswa.

Berdasarkan latar belakang tersebut, dilakukan penelitian tentang uji efektivitas media interaktif integrasi nasional untuk perkuliahan Pendidikan Pancasila dan Kewarganegaraan.

\section{METODOLOGI PENELITIAN}

\section{A. Tujuan Penelitian}

Penelitian ini bertujuan untuk menguji efektivitas media interaktif pembelajaran integrasi nasional pada perkuliahan Pendidikan Pancasila dan Kewarganegaraan.

Menurut Borg dan Gall (2003 dalam Hendrayana 2009) uji efektivitas merupakan uji yang dilakukan terhadap produk yang telah dikembangkan dengan melibatkan calon pengguna produk. Maka efektivitas dapat didefinisikan dengan melakukan pekerjaan yang benar. Uji efektivitas merupakan uji kelayakan yang ada dalam penelitian pengembangan, tujuannya untuk melihat sejauh mana keefektifan produk yang telah dikembangkan. Uji efektivitas ini 
dilakukan untuk mengetahui apakah media interaktif integrasi nasional dapat meningkatkan hasil belajar mahasiswa Universitas Ibn Khaldun Bogor. Efektivitas produk pembelajaran salah satunya dapat dilihat dari aktivitas belajar, dan hasil belajar mahasiswa.

\section{B. Tempat dan Waktu Penelitian}

Lokasi penelitian ini dilaksanakan di Universitas Ibn Khaldun Bogor pada mahasiswa semester 1 Tahun Ajaran 2018/2019.

\section{Metode Penelitian}

Sesuai dengan permasalahan yang diteliti dalam penelitian ini, penilitian ini termasuk jenis penelitian pengembangan. Uji efektivitas media interaktif dilakukan untuk mengukur seberapa efektif media interaktif integrasi nasional dapat meningkatkan aktivitas belajar dan hasil belajar mahasiswa dalam perkuliahan Pendidikan Pancasila dan Kewarganegaraan.

Data efektifitas media interaktif integrasi nasional terhadap hasil belajar dalam penelitian ini dilihat dari presentase mahasiswa yang memperoleh nilai kuis di atas nilai minimal kelulusan. Nilai minimal kelulusan yang ditetapkan Fakultas Keguruan dan Ilmu Pendidikan adalah BC yaitu > 63. Jika lebih dari $80 \%$ mahasiswa memperoleh nilai kuis di atas 63, maka media interaktif dapat dinyatakan efektif.

Pengukuran efektifitas media interaktif terhadap aktivitas pembelajaran dilakukan dengan mengambil data aktivitas pembelajaran yang dilakukan oleh observer, dalam hal ini adalah dosen Pendidikan Pancasila dan Kewarganegaraan. Analisis data aktivitas mahasiswa menggunakan rumus persentase (\%) yang dikemukakan oleh Sudijono dalam Sari dan Susanti (2016) yaitu:

$$
P=\frac{F}{N} x 100 \%
$$

Keterangan:

$\mathrm{P}=$ Presentase efektivitas

$\mathrm{F}=$ Frekuensi aktivitas

$\mathrm{N}=$ Jumlah frekuensi/banyaknya individu

\section{Penilaian observer mengacu pada} lima indikator penilaian yang terdiri atas mempelajari materi yang ada pada media interaktif, berdiskusi antara mahasiswa dengan dosen, berdiskusi antar mahasiswa, menyimpulkan materi pembelajaran, mengerjakan soal-soal latihan (Sari dan Susanti 2016). 
Interpretasi penilaian efektivitas media interaktif terhadap aktivitas mahasiswa disajikan pada Tabel 1 berikut.

Tabel 1. Penilaian Efektifitas Media Interaktif terhadap Aktivitas Belajar Mahasiswa

\begin{tabular}{|c|c|c|}
\hline No. & Interval & Kategori \\
\hline 1 & $76-100 \%$ & $\begin{array}{c}\text { Sangat } \\
\text { Efektif }\end{array}$ \\
\hline 2 & $56-75 \%$ & Cukup Efektif \\
\hline 3 & $40-55 \%$ & Kurang \\
& & Efektif \\
\hline 4 & $<40 \%$ & Tidak Efektif \\
\hline
\end{tabular}

Arikunto (1998: 246).

\section{Populasi dan Sampel Penelitian}

Populasi dalam penelitian ini adalah Mahasiswa Semester 1 Universitas Ibn Khaldun. Sampling penelitian terpilih Mahasiswa Fakultas Keguruan dan Ilmu Pendidikan sejumlah 2 kelas dengan jumlah 50 mahasiswa

\section{HASIL PENELITIAN}

Media interaktif Integrasi Nasional yang dikembangkan dapat dijalankan baik menggunakan perangkat mobile maupun perangkat komputer. Dilihat dari hasil instrumen yang diisi oleh mahasiswa, media interaktif ini dapat membantu meningkatkan motivasi belajar.
Beberapa hal yang harus menjadi perhatian dalam penerapan media interaktif berbasis mobile adalah kompabilitas perangkat smartphone yang dimiliki. Media interaktif ini dapat digunakan baik untuk belajar dalam kelas, belajar berkelompok, maupun sebagai suplemen pembelajaran yang digunakan mahasiswa untuk belajar di Rumah.

Efektifitas media interaktif integrasi nasional dalam penelitian ini dilihat dari presentase mahasiswa yang memperoleh nilai kuis di atas nilai minimal kelulusan. Nilai minimal kelulusan yang ditetapkan Fakultas Keguruan dan Ilmu Pendidikan adalah $\mathrm{BC}$ yaitu > 63. Jika lebih dari $80 \%$ mahasiswa memperoleh nilai kuis di atas 63, maka media interaktif dapat dinyatakan efektif. Berdasarkan hasil observasi pada saat implementasi media interaktif integrasi nasional diperoleh hasil yang disajikan dalam Tabel 2.

Tabel 2. Nilai Kuis Mahasiswa

\begin{tabular}{|c|c|c|}
\hline No. & $\begin{array}{c}\text { Rentang } \\
\text { Nilai }\end{array}$ & $\begin{array}{c}\text { Jumlah } \\
\text { Mahasiswa }\end{array}$ \\
\hline 1 & $>90$ & 12 \\
\hline 2 & $71-90$ & 31 \\
\hline 3 & $51-70$ & 7 \\
\hline 4 & $<50$ & 0 \\
\hline \multicolumn{2}{|c|}{ Jumlah } & 50 \\
\hline
\end{tabular}


Berdasarkan Tabel 2 dari 50 bahwa media interaktif integrasi orang mahasiswa, 12 orang mahasiswa nasional efektif dalam meningkatkan memperoleh nilai kuis lebih dari 90, 31 penguasan konsep integrasi nasional. orang mahasiswa memperoleh nilai Dari data tersebut dapat disimpulkan kuis antara 71-90, dan sisanya 7 orang mahasiswa memperoleh nilai kuis antara 51-70. Secara terperinci bahwa $86 \%$ mahasiswa memperoleh nilai di atas nilai minimal.

presentase nilai kuis mahasiswa diukur dari data aktivitas mahasiswa disajika dalam bentuk diagram pada yang diperoleh selama kegiatan Gambar 1. pembelajaran menggunakan media

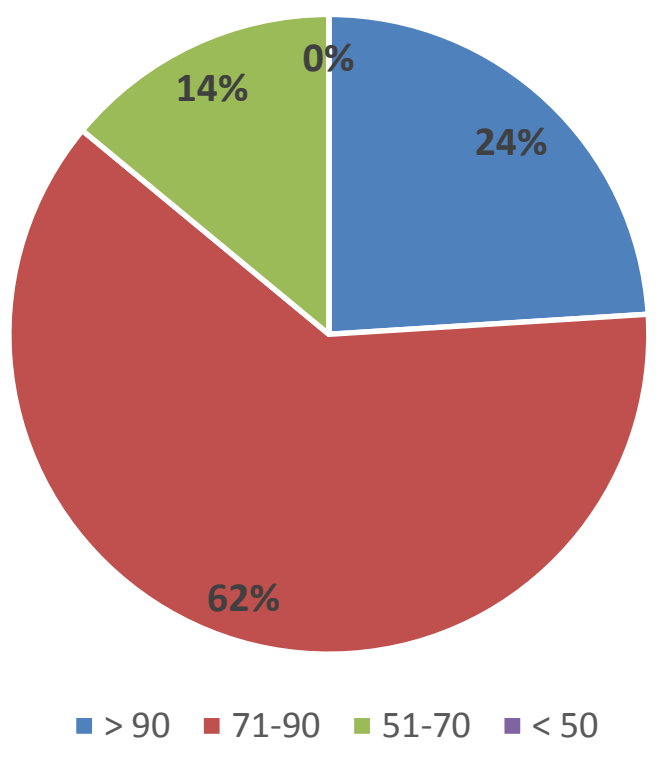

\section{Gambar 1. Presentase Nilai Kuis Mahasiswa}

Berdasarkan Gambar 1 dapat dilihat bahwa mahasiswa yang memperoleh nilai kuis di atas 90 sebanyak $24 \%$ dari 50 orang mahasiswa, $\quad 62 \%$ mahasiswa memperoleh nilai kuis antara 71-90, sedangkan sisanya $14 \%$ mahasiswa memperoleh nilai kuis antara 51-70. Dengan demikian, dapat disimpulkan interaktif Integrasi Nasional. Data diisi oleh observer, yaitu dosen Pendidikan Pancasila dan Kewarganegaraan, dimana penilaian observer mengacu pada lima aspek. Data penilaian observer terhadap aktivitas mahasiswa disajikan pada Tabel 3 berikut. 
Tabel 3. Data Penilaian Observer Terhadap Aktivitas Mahasiswa

\begin{tabular}{|c|c|c|c|}
\hline No. & $\begin{array}{c}\text { Aspek } \\
\text { Penilaian } \\
\text { Aktivitas } \\
\text { Mahasiswa } \\
\end{array}$ & $\begin{array}{c}\% \\
\text { Indikator }\end{array}$ & Kategori \\
\hline 1 & $\begin{array}{l}\text { Mempelajari } \\
\text { materi yang } \\
\text { terdapat pada } \\
\text { media interaktif }\end{array}$ & 92 & $\begin{array}{l}\text { Sangat } \\
\text { Efektif }\end{array}$ \\
\hline 2 & $\begin{array}{l}\text { Berdiskusi } \\
\text { antara } \\
\text { mahasiswa dan } \\
\text { dosen }\end{array}$ & 56 & $\begin{array}{l}\text { Cukup } \\
\text { Efektif }\end{array}$ \\
\hline 3 & $\begin{array}{l}\text { Berdiskusi antar } \\
\text { mahasiswa }\end{array}$ & 84 & $\begin{array}{l}\text { Sangat } \\
\text { Efektif }\end{array}$ \\
\hline 4 & $\begin{array}{l}\text { Menyimpulkan } \\
\text { materi } \\
\text { pembelajaran }\end{array}$ & 80 & $\begin{array}{l}\text { Sangat } \\
\text { Efektif }\end{array}$ \\
\hline 5 & $\begin{array}{l}\text { Mengerjakan } \\
\text { soal-soal latihan }\end{array}$ & 100 & $\begin{array}{l}\text { Sangat } \\
\text { Efektif }\end{array}$ \\
\hline & Jumlah & 408 & \\
\hline & Rata-Rata & 82 & $\begin{array}{l}\text { Sangat } \\
\text { Efektif }\end{array}$ \\
\hline
\end{tabular}

Dari Tabel 3 dapat diketahui bahwa mahasiswa dapat mempelajari materi yang terdapat pada media interaktif dengan presentase 92\% dengan kategori sangat efektif. Dari data ini dapat disimpulkan bahwa media interaktif Integrasi Nasional berbasis Mobile Learning sangat efektif digunakan mahasiswa untuk mempelajari materi yang terdapat pada media interaktif. Pada aspek kedua yaitu berdiskusi antara mahasiswa dan dosen, data hasil penilaian observer terhadap aktivitas mahasiswa menunjukkan bahwa media interaktif cukup efektif dalam membangun diskusi antara mahasiswa dengan dosen dengan presentase $56 \%$. Pada aspek ketiga yaitu berdiskusi antar mahasiswa, data hasil penilaian observer terhadap aktivitas mahasiswa menunjukkan bahwa media interaktif sangat efektif membangun diskusi antar mahasiswa dengan presentase sebesar $84 \%$. Pada aspek keempat yaitu menyimpulkan materi, data hasil penilaian observer menunjukkan bahwa dalam pembelajaran dengan media interaktif Integrasi Nasional berbasis Mobile Learning, mahasiswa dapat menyimpulkan materi dimana nilai presentase penilaian aktivitas mahasiswa sebesar $80 \%$ dengan kategori sangat efektif. Pada aspek kelima yaitu mengerjakan soal-soal latihan, data dari penilaian observer terhadap aktivitas mahasiswa menunjukkan bahawa seluruh mahasiswa mengerjakan soal-soal latihan yang disediakan, sehingga media interaktif dikategorikan sangat efektif.

\section{KESIMPULAN}

Media interaktif integrasi nasional berbasis mobile learning dinilai sangat efektif untuk digunakan berdasarkan penilaian hasil tes mahasiswa dimana $86 \%$ mahasiswa memperoleh nilai di atas nilai minimal, dan penilaian aktivitas mahasiswa oleh observer dengan presentase rata-rata kefektivan sebesar $82 \%$ dengan kategori sangat efektif. 


\section{DAFTAR PUSTAKA}

Nurzaelani, Mohammad Muhyidin,

Kasman, Rusdi. (2018).

Pengembangan Bahan Ajar Integrasi Nasional Berbasis

Mobile, Prosiding SNTP:

Seminar Nasional Teknologi

Pendidikan, Bogor: Program

Studi Teknologi Pendidikan

Universitas Ibn Khaldun Bogor.

Sari, Liza Yulia, Susanti, Diana. (2016).

Uji Efektivitas Media

Pembelajaran Interaktif

Berorientasi Konstruktivisme pada Materi Neurulasi untuk Perkuliahan Perkembangan Hewan. BioCONCETTA, Vol. 2 No. 1: 158-164.

Pimpinan MPR dan Badan Sosialisasi MPR RI Periode 2014-2019. (2017). Materi Sosialisasi Empat Pilar MPR RI, Jakarta: Sekretariat Jenderal MPR RI.

Hendrayana. (2009). Learning Component of Classrom Academic Performance. Journal of Educational Psychology, 82 (1) 33-40.

Arikunto, Suharsimi. (1998). Prosedur Penelitian Suatu Pendekatan Praktek, Jakarta: Rineka Cipta. 